\title{
Seismic Sifting and Design of a Multi- Storeyed Building by Various Materials
}

\author{
C.R Vigneshwar, S.Needhidashan $L$
}

\begin{abstract}
The principle objective of this project is to analyse and design a multi-storied building $[g+10$ (3 dimensional frame)] using staad-pro for different cases like normal building seismic resist building and steel frame building. The design involves load calculations and analysing the whole structure by staad.pro. Staad.pro features a state-of-the-art user interface, analysis and design to visualization and result verification, staad.pro is the professional's choice. Initially we started with the analysis of simple 2 dimensional frames and manually checked the accuracy of the software with our results. The results proved to be very accurate.
\end{abstract}

KEY WORDS: normal building, seismic resist building, steel building, stadd.pro

\section{INTRODUCTION}

This project involves analysis and design of multistoreyed $[G+10]$ for normal building, seismic resist building and steel frame building.

\section{LITERATURE REVIEW:}

Kiyoshi Moto, this study describes a method of analysis of single story and multi-storeyed reinforced concrete buildings.in these buildings, various vertical framing members are framed into and connected to reinforced concrete floor slab structures. The resisting framing elements of building are divided like open frames, walled frames, shear walls.

\section{METHODOLOGY}

\subsection{MATERIAL PROPERTIES}

\subsubsection{FOR NORMAL RCC BUILDING}

Concrete All components in design: M30 grade

\begin{tabular}{|l|l|}
\hline PARAMETER & VALUE \\
\hline FY(Mpa) & 500 \\
\hline FC(Mpa) & 30 \\
\hline
\end{tabular}

Table 2 material properties of normal building

\subsubsection{FOR SEISMIC RCC BUILDING}

Concrete.

All components in design: M30 grade

\begin{tabular}{|l|l|}
\hline PARAMETER & VALUE \\
\hline FY(Mpa) & 500 \\
\hline FC(Mpa) & 30 \\
\hline
\end{tabular}

Table 3 material properties of seismic resist building

\subsubsection{FOR STEEL FRAME BUILDING}

HYSD SECTIONS of grade fe415 confirming to IS18001984 is used FOR beams and columns.

Concrete for footings and for various purposes

All components in design: M30 grade

\begin{tabular}{|l|l|}
\hline PARAMETER & VALUE \\
\hline FY(MPA) & 500 \\
\hline FC(MPA) & 30 \\
\hline
\end{tabular}

Table 4 material properties of steel frame building

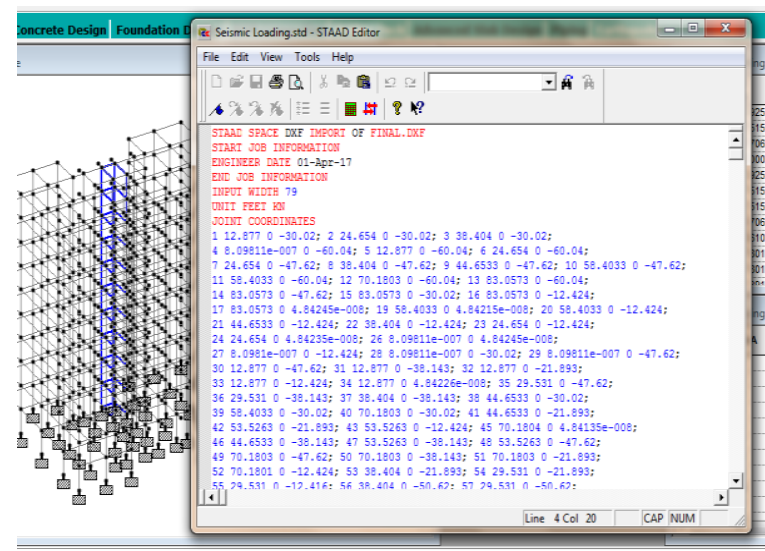

Fig 2: Input Generation

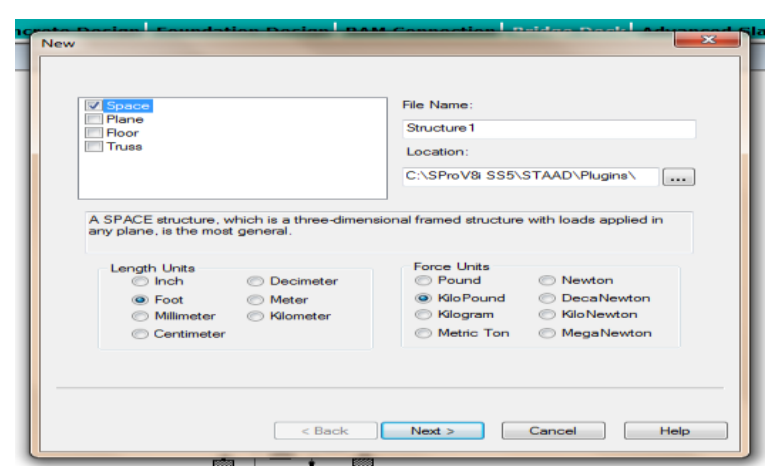

Fig 3: Types of Structures 


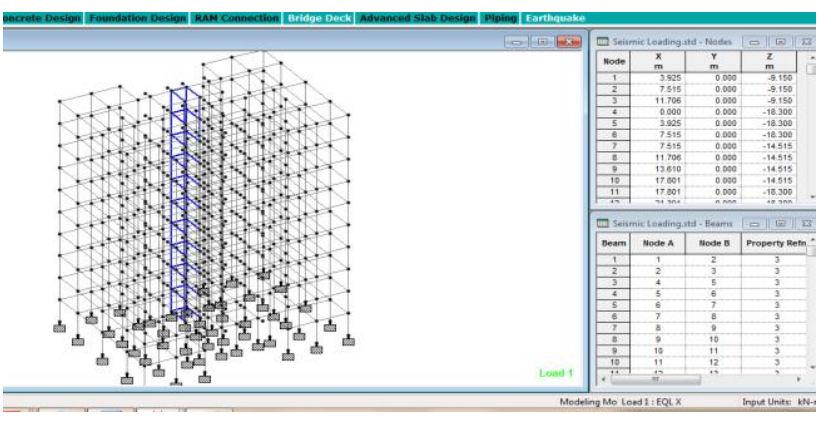

Fig 4: Generation Of Structure

o Fixed support
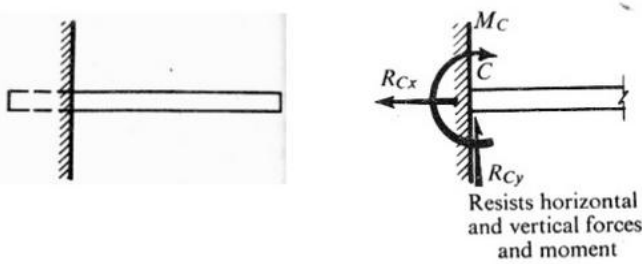

Fig 5: fixed support moments

\subsubsection{Normal building loads}

3.4.5.2

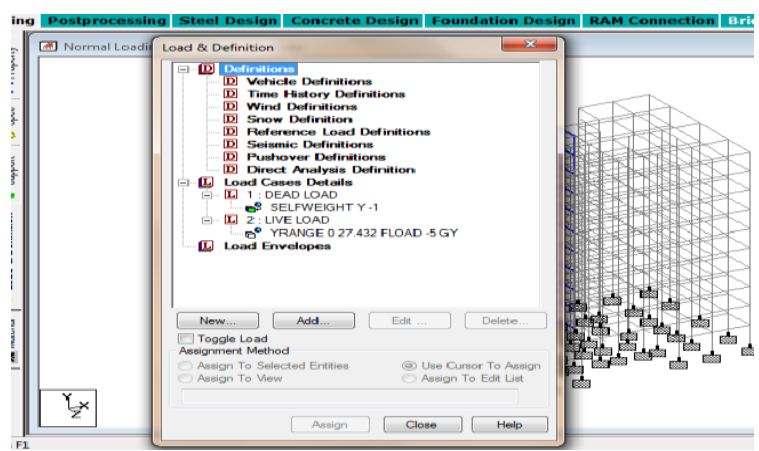

Fig 6: normal building loads \& definition

\subsubsection{Seismic resist building load}

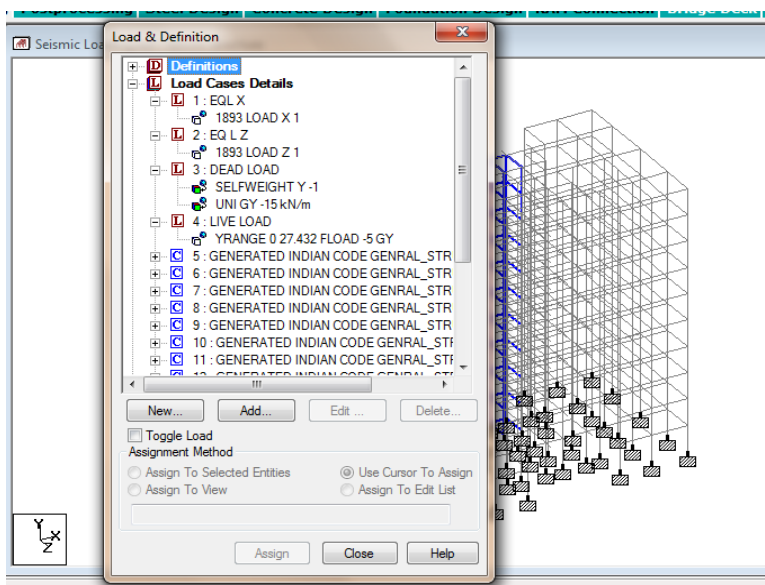

Fig 6: steel building loads \& definition.

\subsubsection{STEEL FRAME BUILDING LOADS}

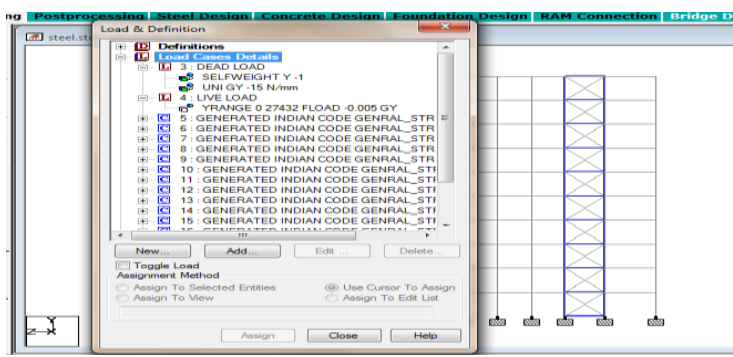

Fig 7: steel frame building loads \& definition.

\subsection{SECTION SPECIFICATIONS FOR THE BUILDING}

For normal RCC building

\begin{tabular}{|l|l|l|l|}
\hline SNO & Description & $\begin{array}{l}\text { Section } \\
\text { type }\end{array}$ & Size of section \\
\hline 1 & Footing & Rectangle & $1.5 \mathrm{M}^{*} 1.5 \mathrm{M}$ \\
\hline 2 & Column & Rectangle & $0.45^{*} 0.45$ \\
\hline 3 & Beam & Rectangle & $\begin{array}{l}0.4 \mathrm{M}^{*} 0.3^{*} \\
\& 0.6 \mathrm{M}^{*} 0.45 \mathrm{M}\end{array}$ \\
\hline 4 & $\begin{array}{l}\text { Surface/slab } \\
\text { thickness }\end{array}$ & & $150 \mathrm{MM}$ \\
\hline
\end{tabular}

Table 5 section specifications for normal building

For seismic resist $\mathrm{RCC}$ building

\begin{tabular}{|l|l|l|l|}
\hline SNO & Description & $\begin{array}{l}\text { Section } \\
\text { type }\end{array}$ & Size of section \\
\hline 1 & Footing & $\begin{array}{l}\text { Rectan } \\
\text { gle }\end{array}$ & $1.6 \mathrm{M}^{*} 1.6 \mathrm{M}$ \\
\hline 2 & Column & $\begin{array}{l}\text { Rectan } \\
\text { gle }\end{array}$ & $\begin{array}{l}0.7 \mathrm{M}^{*} 0.6 \mathrm{M} \\
0.6 \mathrm{M}^{*} 0.5 \mathrm{M}\end{array}$ \\
\hline 3 & Beam & $\begin{array}{l}\text { Rectan } \\
\text { gle }\end{array}$ & $\begin{array}{l}0.5 \mathrm{M}^{*} 0.345 \mathrm{M} \\
\& 0.7 \mathrm{M}^{*} 0.5 \mathrm{M}\end{array}$ \\
\hline 4 & $\begin{array}{l}\text { Surface/slab } \\
\text { thickness }\end{array}$ & & $150 \mathrm{MM}$ \\
\hline
\end{tabular}

Table 6 section specifications for seismic resist building

For steel frame building

\begin{tabular}{|l|l|l|l|}
\hline SNO & Description & Section type & Size of section \\
\hline 1 & Footing & Rectangle & $0.15 \mathrm{M}^{*} 0.15 \mathrm{M}$ \\
\hline 2 & Column & I-SECTION & I100012B50012 \\
\hline 3 & Beam & C-SECTION & ISMC 400 \\
\hline 4 & $\begin{array}{l}\text { Surface/slab } \\
\text { thickness }\end{array}$ & - & - \\
\hline
\end{tabular}

Table 7 section specifications for steel frame building

\section{SCOPE FOR FUTURE STUDY}

The scope is to the achievement of an acceptable probability that structures being designed will perform satisfactorily during their intended life. With an appropriate degree of safety, they should sustain all the loads and

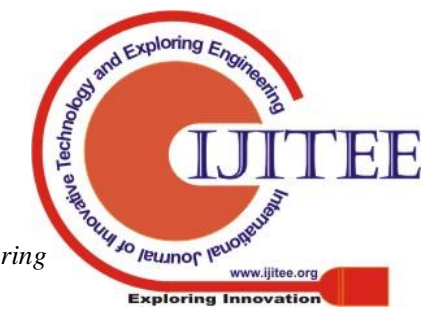


deformations of normal construction and use and have adequate durability and adequate resistance to the effects of seismic and wind. Structure and structural elements shall normally be designed by limit state method. Account should be taken of accepted theories, experiment and experience and the need to design for durability

\section{RESULTS AND DISCUSSION}

\begin{tabular}{|l|l|l|l|}
\hline Output & $\begin{array}{l}\text { Normal } \\
\text { Building }\end{array}$ & $\begin{array}{l}\text { Seismic } \\
\text { Building }\end{array}$ & $\begin{array}{l}\text { Steel } \\
\text { Building }\end{array}$ \\
\hline $\begin{array}{l}\text { Displacement } \\
\text { (y.Max )mm }\end{array}$ & 11 & 3 & 11 \\
\hline $\begin{array}{l}\text { Shear (Y. } \\
\text { Max)mm }\end{array}$ & 13 & 5 & 10 \\
\hline $\begin{array}{l}\text { Bending } \\
\text { Moment(y)m } \\
\text { m }\end{array}$ & 8 & 2 & 9 \\
\hline $\begin{array}{l}\text { Concrete/Ste } \\
\text { el Take Off }\end{array}$ & $\begin{array}{l}877.6 \text { CuM } \\
\text { Of Concrete } \\
\& 80 \text { tonnes } \\
\text { of steel }\end{array}$ & $\begin{array}{l}1272.7 \text { Cum Concrete } \\
\text { \& } 130 \text { tonnes } \\
\text { of steel }\end{array}$ & $\begin{array}{l}1325 \\
\text { steel }\end{array}$ \\
\hline
\end{tabular}

Table 9: Comparison Of Result Of Three Buildings

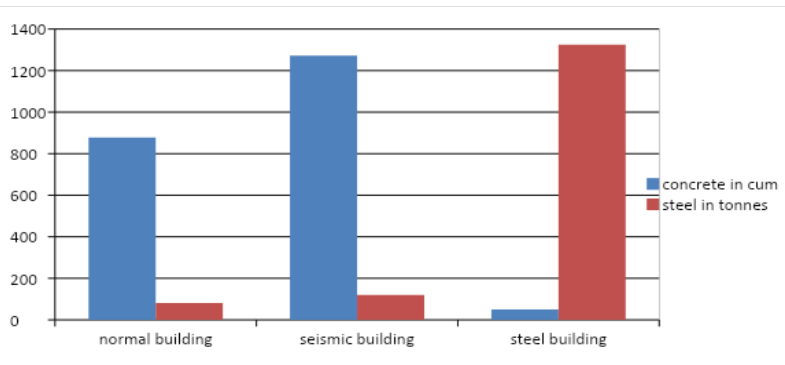

From the above chart there are lot of differences between three types of building;

The displacement of normal building is $0.1 \mathrm{~cm}$,for seismic building is $0 \&$ for steel frame building is $0.1 \mathrm{~cm}$ the three are permissible according to Indian standards from is 456 (2000) and is1893-part 1(2002)

The displacement and shear values are also permissible according to Indian standards from IS 456 (2000) and is1893-part 1(2002)

One of the major important thing is the comparison of the materials in normal building the amount of concrete an steel used IS 877.6 cum of concrete794069.7 $\mathrm{n}$ of steel ,in seismic resist building 1272.7 cum of concrete $969921 \mathrm{n}$ of steel and for steel frame building the amount of steel used is $198655.6 \mathrm{n}$ of steel.

When compared to normal and seismic buildings the amount of materials is increased by nearly $34 \%$ in seismic building whereas in steel frame building the amount of steel used is high

\section{CONCLUSION}

In Earthquake Resistant Design The Quantity Of Materials Increased When Compared To Normal Building.
The Displacement of Beam Coming In the Building Is Within the Limits of Indian Standards

The Maximum Drift in the Building Is $1.8 \mathrm{Cm}$ Which Is Safe As Per IS 1893-2002

The Maximum Beam Displacement Of $5.2 \mathrm{~m}$ San Is $0.024 \mathrm{~mm}$ Allowable Displacement Is $12 \mathrm{~mm}$ As Per IS Code.

\section{REFERENCES}

1. Dr. S.R.Karve\& Dr. V.L. Shah - "Illustrated design of Reinforced concrete Buildings"

2. N. Krishna Raju - "Advanced Reinforced Concrete design"

3. "STAAD Pro 2004 - Getting started \& tutorials" - Published by: R .EI. 